\title{
Is certification an effective tool to improve smallholdings' performance?
}

\author{
Diana Chalil $^{1 *}$ and Riantri Barus ${ }^{1}$ \\ ${ }^{1}$ Department of Agribusiness, Faculty of Agriculture, Universitas Sumatera Utara, Jl. Dr. Mansur No. \\ 9, Medan, Indonesia, 20155
}

\begin{abstract}
Oil palm smallholders have rapidly grown but their performance is relatively low compared to other producer groups. One of the programs that are expected to address this is certification. However, only a small percentage of smallholders received the certification in practice. This study was conducted to analyze the effectiveness of certification to improve smallholder oil palm plantations' performance. The study was conducted in North Sumatra, South Sumatra, and Riau. Data were collected from 707 sample smallholders. Performance is measured from economic aspects, namely productivity, selling prices, fertilizer usage and harvest criteria, and environmental aspects, namely waste treatment and paraquat pesticide usage. The data were then analyzed using the One-Way ANOVA test and the One-Sample t-test. The results show significant differences in productivity and selling prices between the plasma and other smallholder groups, but not between the certified and non-certified ones. The results also show significant differences in the waste treatment between the certified and non-certified groups, but not in paraquat pesticides. Therefore, it can be concluded that certification cannot improve smallholder oil palm plantations' performance if not followed by intensive and sustainable partnership assistance.
\end{abstract}

\section{Introduction}

Palm oil is one of the most widely debated commodities because of its potentially detrimental impacts. In Indonesia, oil palm plantations have totaled 16 million ha of land, significantly impacting the environment. On the other hand, the development of oil palm plantations has significantly contributed to economic growth, not only in producing but also in consuming countries. Certification is designed as an effort to balance environmental and economic impacts. There are two well-known types of certification in Indonesia: international (RSPO) and national (ISPO) certification. Unfortunately, ten years after being introduced, RSPO is deemed ineffective in overcoming environmental impacts [1-4]. Smallholders enjoy special treatment due to their rapid development. However, compared to established companies, smallholders' productivity and best management practices are generally lower, influencing sustainable management in the whole industry. Although there are separate Principles and

*Corresponding author: diana3@usu.ac.id 
Criteria $(\mathrm{P} \& \mathrm{C})$ for schemed and independent smallholders, the prolonged process of smallholder certification has raised questions about the effectiveness of RSPO as a tool for sustainable palm oil management for smallholder oil palm plantations.

As a mandatory certification, ISPO is expected to be a systematic program that will significantly increase the certification rate for oil palm smallholdings. Unfortunately, until 2019 , only 16 smallholder groups with $390,854.18$ ha $(6.56 \%$ of the total smallholder oil palm plantation areas) had received ISPO certificates [5-6]. Besides, the productivity and sustainable management implementation of smallholders are still low [6]. There is no significant progress on ISPO goals to reduce deforestation and GHG, and the certification has not been widely accepted in the global market. These issues need to be considered as global markets are still essential market destinations for Indonesian palm oil products. Up until 2019, 68\% of the Indonesian CPO production is still exported to more than ten countries.

The supervision of oil palm companies to improve smallholdings' performance has been applied since the smallholding's initial development, which is long before certification was launched [7]. Intensive and sustainable supervisions aim to maintain Good Agricultural Practices and Best Management Practices among smallholders. Without continuous supervision, independent smallholders' agricultural practices are likely to vary considerably, influencing the diversity of the smallholders' knowledge, experience, and financial conditions, thus affecting FFB productivity and quality [8].

\section{Method}

Smallholder certifications are group certifications, both for RSPO and ISPO. However, not all smallholders are part of a group. In the 1980s, smallholder oil palm plantations were developed with partner companies' full assistance in the PIR-NES and KKPA programs. They are known as plasma smallholders and are already part of a group from their establishment. As oil palm plantations appear to be more and more profitable, many smallholders independently developed their own. Recently, many of these independent smallholders have received assistance and partnership from oil palm companies. This study utilized clustered samples covering plasma, independent, and independent partnered smallholder groups based on these developments.

This study covers both RSPO and ISPO certifications. Combined with the three partnership types, there are a total of 6 groups of smallholders, namely (1) RSPO certified plasma, (2) ISPO certified plasma, (3) RSPO and ISPO certified independent partnered, (4) ISPO certified independent partnered, (5) RSPO certified independent and (6) non-partnered and non-certified smallholders. Performance is analyzed from economic and environmental aspects, using productivity, selling price, fertilizer application, and harvesting criteria as economic indicators, and waste treatment, and paraquat pesticide usage as environmental indicators. Fertilization is measured using the active ingredients of 3 macro fertilizers, namely Nitrogen, Phosphate, and Potassium. All types and brands of fertilizers used by the smallholders were categorized into these three types. Data were collected from 707 smallholder samples from 3 oil palm plantation center provinces, namely North Sumatra, South Sumatra, and Riau, and were analyzed using one-way ANOVA and One-Sample t-test.

\section{Results and discussion}


The results show that, on average, smallholdings have an area of around 2 ha, hence the need for group certification. Groups are essential in building collective actions, especially for purchasing inputs to reduce average fixed costs and selling outputs to increase bargaining power. However, the performance of each group varies significantly. Plasma smallholders have been involved in well-structured supervised groups from the initial stages of establishment, yet most independent smallholders have not. Several independent smallholders are not members of any group.

The average crop age also varies between groups. Plasma smallholders almost reached the 25 years economic age limit as they are the first established smallholdings. Crops of independent smallholders established later are still in their productive age, albeit with a relatively broad crop age range. Under strict supervision, plasma used the same legitimate/ certified seedlings as their company partners. Independent partnered smallholders that initially built their plantations without company supervision generally still use uncertified seedlings. Previous studies showed that even with the same fertilizer application, certified and uncertified seedlings' productivity could differ by up to $40 \%$ [9].

In the development of smallholder certification, plasma and independent partnered groups are not the only ones who have succeeded in receiving sustainable certificates; non-partnered independent smallholders are also recorded among those who do. They were technically and financially supported by NGOs, the government, and companies to prepare the documents and improve conditions related to the certification P\&C. However, the support given does not intensively and continuously cover acceptable agricultural practices, unlike those received by plasma smallholders. For example, herbicide application support focuses on changing the method from plantation-wide application to limiting only on the circle around the crops and on the path for harvesting Fresh Fruit Bunches (FFB). However, companies and NGOs do not focus on ensuring the use of recommended types and amounts of fertilizer. In detail, the different characteristics among the six types of smallholder groups can be seen in the Table 1.

Table 1. Smallholding characteristics based on smallholder groups.

\begin{tabular}{|l|c|c|c|c|c|c|c|c|c|}
\hline \multirow{2}{*}{ Group } & \multicolumn{3}{|c|}{ Land Size (ha) } & \multicolumn{3}{c|}{ Crop age (Year) } & \multicolumn{3}{c|}{ Year of Certified (year) } \\
\cline { 2 - 11 } & Min & Max & Average & Min & Max & Average & Min & Max & Average \\
\hline RSPO plasma & 2.00 & 6.00 & 2.13 & 14.00 & 31.00 & 24.97 & 4.00 & 14.00 & 7.60 \\
\hline ISPO plasma & 2.00 & 2.00 & 2.00 & 22.00 & 26.00 & 24.73 & 2.00 & 2.00 & 2.00 \\
\hline $\begin{array}{l}\text { ISPO-RSPO } \\
\text { partnered } \\
\text { independent }\end{array}$ & 1.65 & 2.50 & 1.98 & 16.00 & 22.00 & 19.84 & 4.00 & 8.00 & 5.36 \\
\hline $\begin{array}{l}\text { ISPO partnered } \\
\text { independent }\end{array}$ & 2.70 & 2.80 & 2.78 & 15.00 & 16.00 & 15.50 & 1.00 & 1.00 & 1.00 \\
\hline $\begin{array}{l}\text { RSPO } \\
\text { independent } \\
\text { non partnered }\end{array}$ & 0.58 & 7.00 & 2.60 & 8.00 & 38.00 & 17.10 & 3.00 & 3.00 & 3.00 \\
\hline $\begin{array}{l}\text { Non certified - } \\
\text { non partnered }\end{array}$ & 0.08 & 24.00 & 2.44 & 4.00 & 35.00 & 18.46 & & & \\
\hline
\end{tabular}

The results also show differences in performance among the groups, especially in the economic aspect. Plasma smallholders with crops that almost exceed the economic age still have higher average productivity than other groups with productive crop age. As predicted, the non-partnered and uncertified groups have the lowest productivity and an extensive range between the minimum and maximum levels, which is 0.225 tons $/$ ha/month and 3,080 tons/ha/month, respectively. Similar results can also be seen in the average selling price. 
Plasma smallholders enjoy high government selling prices (Disbun price), although not the highest as the government prices are differentiated based on crop age. They are incentivized for providing quality FFB by partner companies through higher prices. They also follow the harvesting criteria with supervision from partner companies. Details of the average productivity and selling price of each group are as follows.

Table 2. Average productivity and selling price based on smallholder groups.

\begin{tabular}{|c|c|c|c|c|}
\hline Factors & Groups & Mean & Minimum & Maximum \\
\hline \multirow{6}{*}{$\begin{array}{l}\text { Productivity } \\
\text { (ton/ha/month) }\end{array}$} & RSPO plasma & 2.099 & 1.313 & 2.318 \\
\hline & ISPO Plasma & 2.192 & 1.538 & 3.225 \\
\hline & $\begin{array}{l}\text { ISPO-RSPO partnered } \\
\text { independent }\end{array}$ & 2.036 & 1.321 & 2.985 \\
\hline & ISPO partnered independent & 1.820 & 1.088 & 1.988 \\
\hline & RSPO independent non partnered & 1.673 & 1.020 & 2.625 \\
\hline & Non certified - non partnered & 1.409 & .225 & 3.080 \\
\hline \multirow{6}{*}{$\begin{array}{l}\text { FFB Selling Price } \\
\text { (IDR/kg) }\end{array}$} & RSPO plasma & 1416 & 1146 & 1514 \\
\hline & ISPO Plasma & 1763 & 1763 & 1763 \\
\hline & $\begin{array}{l}\text { ISPO-RSPO partnered } \\
\text { independent }\end{array}$ & 1482 & 1300 & 1665 \\
\hline & ISPO partnered independent & 1394 & 1394 & 1394 \\
\hline & RSPO independent non partnered & 1243 & 1080 & 1410 \\
\hline & Non certified - non partnered & 1060 & 350 & 1550 \\
\hline
\end{tabular}

Productivity and selling prices can be used to measure improvements in the quantity and quality of smallholdings. However, the One-way ANOVA test results show that productivity does not significantly differ between groups and vice versa for selling prices.

Table 3. One Way ANOVA test results.

\begin{tabular}{|c|c|c|c|c|c|c|}
\hline Description & $\begin{array}{c}\text { ISPO } \\
\text { independent } \\
\text { partnered }\end{array}$ & $\begin{array}{c}\text { ISPO-RSPO } \\
\text { independent } \\
\text { partnered }\end{array}$ & $\begin{array}{l}\text { RSPO } \\
\text { plasma }\end{array}$ & $\begin{array}{c}\text { Non- } \\
\text { partnered- } \\
\text { non } \\
\text { certified } \\
\end{array}$ & $\begin{array}{l}\text { ISPO } \\
\text { Plasma }\end{array}$ & $\begin{array}{c}\text { RSPO } \\
\text { independent } \\
\text { non } \\
\text { partnered } \\
\end{array}$ \\
\hline \multicolumn{7}{|l|}{ Productivity } \\
\hline $\begin{array}{l}\text { ISPO } \\
\text { independent } \\
\text { partnered }\end{array}$ & & 0.606 & 0.228 & $0.004^{*}$ & 0.166 & 0.976 \\
\hline $\begin{array}{l}\text { ISPO-RSPO } \\
\text { independent } \\
\text { partnered }\end{array}$ & 0.606 & & 0.987 & $0.000 *$ & 0.858 & 0.345 \\
\hline RSPO plasma & 0.228 & 0.987 & & $0.000^{*}$ & 0.976 & 0.142 \\
\hline $\begin{array}{l}\text { Non partnered- } \\
\text { non certified }\end{array}$ & $0.004 *$ & $0.000 *$ & $0.000 *$ & & $0.000 *$ & 0.603 \\
\hline ISPO Plasma & 0.166 & 0.858 & 0.976 & $0.000 *$ & & 0.093 \\
\hline $\begin{array}{l}\text { RSPO } \\
\text { independent } \\
\text { non partnered }\end{array}$ & 0.977 & 0.049 & 0.142 & 0.603 & 0.093 & \\
\hline $\begin{array}{l}\text { FFB selling } \\
\text { price }\end{array}$ & & & & & & \\
\hline
\end{tabular}




\begin{tabular}{|c|c|c|c|c|c|c|}
\hline $\begin{array}{l}\text { ISPO } \\
\text { independent } \\
\text { partnered }\end{array}$ & & 0.067 & 0.977 & $0.000 *$ & $0.000 *$ & $0.015^{*}$ \\
\hline $\begin{array}{l}\text { ISPO-RSPO } \\
\text { independent } \\
\text { partnered }\end{array}$ & 0.067 & & 0.049 & $0.000 *$ & $0.000^{*}$ & $0.000 *$ \\
\hline RSPO plasma & 0.977 & $0.049^{*}$ & & $0.000 *$ & $0.000 *$ & $0.000^{*}$ \\
\hline $\begin{array}{l}\text { Non partnered- } \\
\text { non certified }\end{array}$ & $0.000 *$ & $0.000^{*}$ & $0.000 *$ & & $0.000 *$ & $0.000^{*}$ \\
\hline ISPO Plasma & $0.000 *$ & $0.000^{*}$ & $0.000 *$ & $0.000 *$ & & $0.000 *$ \\
\hline $\begin{array}{l}\text { RSPO } \\
\text { independent } \\
\text { non partnered }\end{array}$ & $0.000 *$ & $0.000^{*}$ & $0.000 *$ & $0.000 *$ & $0.000^{*}$ & \\
\hline
\end{tabular}

*significantly different at 5\%

Differences in productivity mainly stem from seedling and variations in fertilizer application among the six groups. Table 4 shows that on average, plasma smallholders that underwent intensive supervision apply the recommended amount of Nitrogen and Potassium. In contrast, neither certified nor uncertified independent smallholders use the recommended amount. Surprisingly, non-partnered-non-certified smallholders appear to use higher amounts of macro fertilizers. However, the range between the minimum and maximum levels is significant, indicating low levels of knowledge and high financial capabilities variation. In general, none of the smallholders used Phosphate as recommended. In contrast, 3 out of 4 partnered groups used a higher amount of Potassium than recommended to increase FFB. Details of the macro fertilizer application among the groups can be seen in Table 4.

Table 4. Fertilizer application among smallholder groups ( $\mathrm{kg} / \mathrm{ha} / \mathrm{year})$.

\begin{tabular}{|c|c|c|c|c|c|c|c|c|c|}
\hline \multirow{2}{*}{ Description } & \multicolumn{3}{|c|}{ Nitrogen } & \multicolumn{3}{|c|}{ Phosphate } & \multicolumn{3}{|c|}{ Potassium } \\
\hline & Min & Max & Average & Min & Max & Average & Min & Max & Average \\
\hline RSPO Plasma & 69.00 & 184.00 & 149.69 & 54.00 & 70.20 & 61.10 & 240.00 & 420.00 & 317.15 \\
\hline ISPO Plasma & 184.00 & 184.00 & 184.00 & 67.50 & 81.00 & 73.02 & 240.00 & 240.00 & 240.00 \\
\hline $\begin{array}{l}\text { ISPO-RSPO } \\
\text { partnered } \\
\text { independent }\end{array}$ & 42.00 & 189.00 & 120.03 & 20.25 & 216.00 & 83.91 & 120.00 & 600.00 & 342.95 \\
\hline $\begin{array}{l}\text { ISPO partnered } \\
\text { independent }\end{array}$ & 80.00 & 80.00 & 80.00 & 80.00 & 80.00 & 80.00 & 80.00 & 80.00 & 80.00 \\
\hline $\begin{array}{l}\text { RSPO independent } \\
\text { non partnered }\end{array}$ & 20.00 & 186.00 & 90.05 & 22.50 & 90.00 & 55.75 & 20.00 & 57.00 & 44.20 \\
\hline $\begin{array}{l}\text { Non certified - non } \\
\text { partnered }\end{array}$ & 7.50 & 498.00 & 137.56 & 7.50 & 360.00 & 84.87 & 7.50 & 380.00 & 98.21 \\
\hline Recommendation & 115.12 & 180.90 & 148.01 & 64.35 & 115.83 & 90.09 & 107.25 & 193.05 & 150.15 \\
\hline
\end{tabular}

In contrast to the economic aspects, waste treatment is significantly changed by certifications. All certified groups have washed or appropriately dumped used fertilizer sacks or pesticide containers. Due to both RSPO and ISPO P\&C, this indicator is a priority both in the document check and field observations. Moreover, this extra activity does not need significant additional labor, time, or cost.

Table 5. waste treatment among smallholder groups. 


\begin{tabular}{|l|c|c|}
\hline \multirow{2}{*}{\multicolumn{1}{|c|}{ Group }} & \multicolumn{2}{c|}{ Waste treatment (\%) } \\
\cline { 2 - 3 } & No & Yes \\
\hline RSPO plasma & 0 & 100 \\
\hline ISPO Plasma & 0 & 100 \\
\hline ISPO-RSPO partnered independent & 0 & 100 \\
\hline ISPO partnered independent & 0 & 100 \\
\hline RSPO independent non partnered & 0 & 100 \\
\hline Non certified - non partnered & 93 & 7 \\
\hline
\end{tabular}

However, a similar change has not appeared in paraquat pesticide usage. Paraquat is prohibited as it is considered harmful to the environment and human health [10]. The consequences can partly explain this condition if replacing paraquat pesticides such as Gramoxone with other herbicides, such as needing to apply herbicides more often, especially in watery lands such as swamps, which equals more labor and production costs. In the RSPO $\mathrm{P} \& \mathrm{C}$, the recommendation to minimize paraquat usage is only a minor indicator [11] and not explicitly stated in the ISPO [12]. For the non-partnered and uncertified group, the low paraquat usage was mainly due to funding. As an alternative, they simply cut or let weeds grow on their plantation. Under such conditions, many smallholders are still using paraquat pesticides, including those that have received ISPO certification.

Table 6. Paraquat usage among smallholder groups.

\begin{tabular}{|l|r|r|}
\hline \multicolumn{1}{|c|}{ Group } & Using paraquat & Not using paraquat \\
\hline RSPO plasma & 11.538 & 88.462 \\
\hline ISPO Plasma & 72.727 & 27.273 \\
\hline ISPO-RSPO partnered independent & 34.091 & 65.909 \\
\hline ISPO partnered independent & 95.455 & 4.545 \\
\hline RSPO independent non partnered & 0.000 & 100.000 \\
\hline Non certified - non partnered & 30.261 & 69.739 \\
\hline
\end{tabular}

\section{Conclusion}

In conclusion, unless supported by strong partnerships with palm oil companies, RSPO and ISPO certifications do not prove useful tools in improving oil palm smallholdings. Partnerships need to involve intensive, long-term supervisions, both in the technical and financial fields, from well-performing oil palm companies.

\section{Acknowledgements}

This study is funded by Penelitian Terapan 2020, Hibah TALENTA Lembaga Penelitian Universitas Sumatera Utara.

\section{References}


1. N. K. Hidayat, A. Offermans, P. Glasbergen, Sustainable palm oil as a public responsibility? On the governance capacity of Indonesian Standard for Sustainable Palm Oil (ISPO), Agric Hum Values. 35 (2018)

2. N. K. Hidayat, At the bottom of the value chain: sustainability certification and palm oil smallholders' livelihoods in Indonesia. Data wise/Universitaire Pers Maastricht (2017) https://doi.org/10.26481/dis.20170928nkh,

3. S. Hutabarat, ISPO certification and Indonesian oil palm competitiveness in global market smallholder challenges toward ISPO Certification: Sertifikasi Ispo dan Daya Saing Kelapa Sawit Indonesia di Pasar Global Tantangan Perkebunan Rakyat Menghadapi Sertifikasi ISPO, Agro Ekonomi. 28, 2 (2017)

4. C.L Morgans et al., Evaluating the effectiveness of palm oil certification in delivering multiple sustainability objective, Environ. Res. Lett. 13064032 (2018)

5. ISPO, ISPO Certificate http://www.ispoorg.or.id/index.php?option=com_content $\&$ view=article\&id=79\&Itemid=225\&lang= ina

6. Tree Crop Estate Statistics of Indonesia 2017 - 2019, Secretariate of Directorate General of Estate Crops, Directorate General of Estate Crops, Ministry of Agriculture (2018)

7. E. Hamid, Z. Fathoni, M. Yanita, Palm oil sustainability partnership: implementation and connection with farmers income, E3S Web of Conference. 52 (2018)

8. E. D. Innocenti, P. Oosterveer, Opportunities and bottlenecks for upstream learning within RSPO certified palm oil value chains: A comparative analysis between Indonesia and Thailand, Journal of Rural Studies. 78 (2020)

9. J.P.C., Baskett, J.Ch, Jacquemard, T. Durand-gasselin, E. Suryana, H. Saelanie, E. Dermawan, Planting Material as KeyInput for Sustainable Palm Oil”, Journal of Oil Palm Research, Special Issue (2008)

10. Centres for Disease Control and Prevention, U.S. Department of Health \& Human Services https://emergency.cdc.gov/agent/paraquat/basics/facts.asp

11. Roundtable on Sustainable Palm Oil, Principles and Criteria for Sustainable Palm Oil Production 2018 The Indonesia National Interpretation (2018)

12. S.G. Naggara, L. Rosalina, R.Y. Kartika, A.A. Setyawan, 6 tahun ISPO, Forest Watch Indonesia (2017) 